NBER WORKING PAPER SERIES

\title{
PARTISAN CYCLES IN CONGRESSIONAL ELECTIONS AND THE MACROECONOMY
}

Alberto Alesina

Howard Rosenthal

Working Paper No. 2706

\author{
NATIONAL BUREAU OF ECONOMIC RESEARCH \\ 1050 Massachusetts Avenue \\ Cambridge, MA 02138 \\ September 1988
}

A preliminary version of this paper was presented at the meeting of the Public Choice Society in San Francisco, March 1988. Prepared for delivery at the conference on "Economic Models of Politics", Haifa University, June 1923, 1988. We thank Brian Roberts and Peter Van Doren for comments and Ray Fair for sharing his data. This research is part of NBER's research program in Financial Markets and Monetary Economics. Any opinions expressed are those of the authors not those of the National Bureau of Economic Research. 
NBER Working Paper \#2706

September 1988

\section{PARTISAN CYCLES IN CONGRESSIONAL}

ELECTIONS AND THE MACROECONOMY

\section{ABSTRACT}

The post-war United States exhibits two rather strong politico-economic regularities. The political regularity is that the party of the President has always lost votes in mid-term Congressional elections, relative to its Congressional vote in the previous elections; the economic regularity is that Republican administrations exhibit below average economic growth in the first half of each term and Democratic administrations are associated with above average growth in their first half. In the second halves economic growth is similar under the two administrations. We provide a rational expectations model which can explain these two regularities. In Presidential elections voters have to choose between two polarized candidates; mid-term elections are used to counterbalance the President's polictes by strenghtening the opposition in Congress. Since presidents of different parties are associated with different economic polfcies, our model predicts a (spurfous) correlation between the state of the economy and elections. The predictions of our model are in sharp contrast with those of traditional retrospective voting models in which voters simply reward the incumbent if the economy is doing well immediately before the election. Our empirical results suggest that our model performs at least as well and often better than alternative models. In addition, we question previous claims that voters are short sighted and naively backward looking.

Alberto Alesina

GSIA

Carnegie-mellon University

Pittsburgh, PA 15213
Howard Rosenthal

GSIA

Carnegie-Mellon University

Pittsburgh, PA 15213 


\section{Introduction}

There is increasing awareness of a high degree of interdependence between macroeconomics and macropolitics. ${ }^{1}$ In the years since the conclusion of the Second World War in the United States there have been some strong empirical regularities in both the economic and political areas. A political regularity, the midterm Congressional cycle, is well known. As shown in Figure 1, the party holding the white House has lost vote share in mid-term elections both in the House and in the senate. The figure shows the Republican percent of the two party vote. For the intervals between "on" and "off" years (48-50, 52-54, etc.), the curves always slope downwards with a Republican in office and upwards with a Democratic president. The same regularity holds for seats in the House of Representatives.

A macroeconomic regularity was first noted by Hibbs (1977), who showed that unemployment tended to fall when the Democrats occupied the White House and rose on a Republican watch. ${ }^{2}$ Alesina and Sachs (1988), Alesina (1988a) and Chapell-Keech (1988) refined this observation, by showing that real GNP tends to increase at above average rates in the first two years of Democratic administrations and increases at below average rates in the first two years of Republican administrations, while the second halves of the two administrations show very little difference, if any (see Table 1). Similar results hold for unemployment. In particular, five of the seven postwar recessions have started soon after a Republican President was elected. Complementing these results on output and unemployment, several researchers, including Beck (1982, 1984a), Hibbs (1987), Havrilesky (1987), Alesina and Sachs (1988), Alesina (1988a), Tabellini and La Via (1986), Chappell and Keech (1988), find that monetary policy has been "looser", thus more 
inflationary, when a Democratic, rather than Republican, was in the White House.

In this essay, we present a model that is consistent with these two regularities. Individual agents in both the economy and the electorate are fully rational and forward-looking. " "Frictions" in the economy and the political process generate the observed cyclical behavior. The political "friction" is that candidates have polarized policy preferences." Democrats, for example, have a higher tolerance for inflation and a lower tolerance for unemployment than do Republicans. Because the outcome of elections cannot be fully anticipated, these policy preferences will lead to expectation uncertainey. The economic "friction" is that plans and contracts made prior to elections cannot be immediately revised once the winner is known. In addition, in the model, economic agents cannot enter into state contingent contracts that provide insurance against electoral risk. Specifically, some wage contracts are signed before it is known which inflation rate will occur after the election, since there is electoral uncertainty. Thus, even a rational public cannot predict with certainty the post-election inflation rate: this generates a short-run Phillips curve, even in a rational expectations model. However, since contracts and plans can be reformulated after the election, the real effects diminish over time, and eventually disappear. This is consistent with the observation that the real effects on output and unemployment are largely concentrated at the beginning of each administration. 5

The inability to anticipate elections also affects the behavior of pivotal voters, that in our model, are moderate relative to either party. They would like policies in between those pursued by Democratic and 
Republican presidents. Since we assume that actual policy is unidimensional and a function of the preferences of the executive and of the relative strength of the two parties in Congress, pivotal voters can use their Congressional votes to moderate the outcomes of Presidential elections.

Some of this moderating behavior may take place in Presidential years, consistent with the empirical observation of massive split-ticket voting in the American electorate. ${ }^{6}$ In mid-term elections, additional moderation of the President should take place. Thus, there will be a shift in allegiance of some voters who supported the President's party during the Presidential election. This shift generates the midterm electoral cycle. Thus, our model does not consider "coattails" and other explanations of the midterm cycle. Instead, the purpose of this paper is to present a model that is consistent with both this regularity and the regularity concerning the macroeconomy .

We eliminate other potential "frictions" in order to make the model tractable. Specifically, we assume that (a) there are no lagged effects in the policy or the economy, and (b) voters are perfectly informed about the preferences of the policymakers and about the state of the economy. These assumptions eliminates any incumbency effect. In addition, since macroeconomic variables depend only upon current government policy and agents' expectations of those policies, there is no carry over from past policies.' Consequently, we can examine each Presidential election and the ensuing Congressional election as a two-period game, isolated from past and future history.

Matters are further simplified--both for tractability and to highlight the key elements of our model--by assuming that the only source of 
uncertainty is about the distribution of voter preferences. Thus, we have eliminated several important sources of uncertainty. For one, preferences of Presidential candidates are assumed known prior to an election. For another, there are no exogenous shocks to the economy. As a result, voters do not need to learn anything about the preferences or competence of politicians from observing the state of the economy. ${ }^{8}$ If learning takes place, we would find retrospective as well as moderating voting. In addition to restricting the form of uncertainty, we also later make further simplifying assumptions for technical reasons. We conjecture that the qualitative nature of our results holds in more general specifications.

The predictions of our model contrast sharply with those of other politico-economic models. Nordhaus (1975) suggested that administrations faced non-rational agents and could therefore create an expansion immediately before elections. This "electoralist" policy would be followed by both parties, since they both care only about reelection. McCallum (1978), (and several others after him) provided a substantial body of empirical results rejecting the Nordhaus model. An alternative to Nordhaus is provided by Hibbs' "partisan" cycle. The Hibbs work, however, remains similar to Nordhaus' in the assumption of non-rational economic agents, since it is based upon a traditional Phillips curve.

On the political side, the major alternative to our model is the retrospective voting formulation introduced by Kramer (1971). [See also Fiorina (1981)]. In retrospective models, voters vote for the incumbent president's party in good times and go against it in bad times. Moreover, as argued. in most detail by Fair $(1978,1982,1987)$, the data would suggest that voters have short memories. Only the state of the economy in the six months 
prior to the election has any bearing on the election results. In contrast, in the model we present here, voters vote solely to influence the future of the economy. Past performance is irrelevant. Since pivotal voters seek moderation and since the first two years of administrations will lead to fluctuations in output, our model does point to an expected correlation between past economic performance and voting behavior. In "off" years, voting for the Democrats should be negatively correlated with the deviation from the longterm growth rate of the economy. The reason is that years of. above average growth will occur under a Democratic president. When the electorate votes to moderate Democratic presidents, the Democratic Congressional vote will decline. In years when the Democrats hold the White House, the prediction of our model contrasts sharply with that of Kramer-Fair. In years of below average growth--produced by Republican presidents--the two models agree in predicting the Democrats will do well.

Because our model leads to different predictions than the literature, Section 3 of this paper presents some empirical analysis of aggregate election results since World war II. We find that much previous work, particularly Kramer's, fails to replicate on this period whereas our model tests out rather well. Our results cover both the Senate as well as the House of Representatives. The empirical section is preceded, in section 2 , by a formal presentation of our theoretical model. Concluding remarks are contained in Section 4.

\section{The Model}

As in Alesina (1987) the economy is described by a nominal wage contract model, based upon Fischer (1977). In this model wage setters attempt to 
maintain the real wage at the level compatible with the natural rate of unemployment. Labor contracts last one period and are signed at the end of, say, period $(t-1)$ for period $t$. These contracts are non-contingent; in particular, full indexation is excluded. Thus, wage setters set the nominal wage growth equal to expected inflation:

$$
w_{t}-\pi_{t}^{0}-E\left(\pi_{t} \mid I_{t-1}\right)
$$

where $w_{t}=$ nominal wage growth; $\pi_{t}$ - rate of inflation; $E(\cdot)$ is the mathematical expectation operator; $I_{t-1}$ is the information set available in period $(t-1)$. The superscript e indicates rationally expected variables. Given (1) the supply function for this economy can be written as follows:

$$
\mathrm{y}_{t}-\gamma\left(\pi_{t}-\pi_{t}^{0}\right)+\overline{\mathrm{y}} \quad \gamma>0 ; \overline{\mathrm{y}} \geq 0
$$

where $y_{t}$ is the rate of growth of output and $\bar{y}$ is the rate of growth of output compatible with the natural rate of unemployment. Throughout this paper we assume that the rate of inflation can be controlled directly by the policymakers. ${ }^{10}$

Electoral competition has the following structure. Every two periods, say in periods $t=0,2,4, \ldots$, Presidential elections are held; in these elections a President and Congress are elected: we refer to "Congress" as the unique legislative body. In non-Presidential elections years (i.e., $t$ - 1 , $3,5, \ldots)$ a new Congress is elected. The two candidates for President are labelled $D$ and $R$, and since we do not distinguish between "candidates" and "parties" the two terms are used interchangeably. The objective functions of the candidates, defined on output and inflation are given by (the superscripts identify the party): 


$$
\begin{aligned}
& u^{D}=-\sum_{t=0}^{\infty} \beta^{t}\left[\frac{1}{2}\left(\pi_{t}-\vec{x}^{D}\right]^{2}+\frac{b^{D}}{2}\left[y_{t}-k^{D}\right)^{2}\right] \\
& u^{R}=-\sum_{t=0}^{\infty} \beta^{t}\left[\frac{1}{2}\left(\pi_{t}-\vec{x}^{R}\right)^{2}+\frac{b^{R}}{2}\left[y_{t}-k^{R}\right)^{2}\right]
\end{aligned}
$$

The difference in the objectives of the two parties can be captured by the following inequalities:

$$
\overrightarrow{\mathrm{x}}^{\mathrm{D}} \geq \overrightarrow{\mathrm{x}}^{\mathrm{R}} ; \quad \mathrm{b}^{\mathrm{D}} \geq \mathrm{b}^{\mathrm{R}} ; \quad \mathrm{k}^{\mathrm{D}} \geq \mathrm{k}^{\mathrm{R}}
$$

The two parties are not identical if at least one of the three inequalities in (5) holds strictly. The first one highlights a difference in the desired inflation rate, which can be related to a different need for the inflation tax, for instance because the two parties disagree about the optimal level of government spending. The second and third inequalities capture a different evaluation of the costs on inflation and unemployment. In order to simplify the exposition as much as possible, we restrict the difference between the two parties' objectives to the first inequality (which we assume strict) and we impose $b^{D}=b^{\mathbb{R}}=0$. There is no loss of generality in this simplification because if we substitute (2) into (3) and (4) we would still obtain unidimensional objective functions on inflation, with different optimal and time consistent policies for the two parties. ${ }^{11}$ Thus the objective functions of the two parties are:

$$
\begin{gathered}
U^{D}=\sum_{t=0}^{\infty} \beta^{t} u_{t}^{D}=-\sum_{t=0}^{\infty} \beta^{t}\left[\frac{1}{2}\left[\pi_{t}-\bar{x}^{D}\right)^{2}\right] \\
U^{R}=\sum_{t=0}^{\infty} \beta^{t} u_{t}^{R}=-\sum_{t=0}^{\infty} \beta^{t}\left[\frac{1}{2}\left(\pi_{t}-\bar{x}^{-R}\right)^{2}\right]
\end{gathered}
$$


Voters, like the candidates, have quadratic preferences defined on inflation and know the preferences of the two parties, i.e., they know (6) and (7). We assume a continuum of voters where the distribution of voters' bliss points $\left(x^{i}\right)$, with $i$ denoting the generic voter, is uniform. Without further loss of generality, this distribution is of unit length. Its extremes are given by:

$$
[a, 1+a]
$$

where $a$ is a random variable with zero mean distributed on $\left[a^{\min }, a^{\max }\right]$. We also impose the following inequalities:

$$
a^{\max }<\vec{x}<\vec{x}<1+a^{\min }
$$

which imply that for any realization of voters' preferences, there are voters with bliss points on both sides of $\bar{x}^{R}$ and $\vec{x}$. The distribution of $a$ and the unit length of the voter distribution are "common knowledge". Since voters" preferences are random, the electoral results are probabilistic even if there is no uncertainty about the policies followed by the two parties if elected.

As a benchmark, consider the case in which "Congress" has no impact on the inflation policy (or, assume that "Congress" does not exist). In this case, presidents follow these policies:

$$
\pi_{j}^{R}-\vec{x}^{R}, \pi_{j}^{D}=\vec{x}^{D}, j=t, t+1
$$

Voters rationally expect these policies and vote accordingly. In particular, each voter votes for the party with the bliss point closest to his own. The probability of electing the $D$ is then given by the probability that the realization of the random variable a is such that more than 50 percent of the 
voters have a bliss point closer to $\bar{x}^{D}$ than to $\bar{x}$. We indicate this value with $\overline{\mathrm{P}}$.

Note that in this model the candidates do not convergence fully as in standard median voter models, nor do they partially converge as in the case of ideologically motivated candidates studied by Wittman (1977, 1983), and Calvert (1985). In fact, as shown in Alesina (1988b), the two presidents cannot commit to any platform other than (10). For instance, if candidate $D$ could precommit to a preelectoral platform he would choose a convergent policy, lower than his bliss point, in order to capture (probabilistically) middle-of-the-road voters. However, if precommitments are ruled out, voters know that when in office, the presidents would follow their most preferred policies. Thus, lacking a precommitment technology there cannot be any policy convergence. ${ }^{12}$

Expected inflation is given by:

$$
\begin{array}{ll}
\pi_{t}^{0}-\overline{\mathrm{P}} \overline{\mathrm{x}}^{\mathrm{D}}+(1-\overline{\mathrm{P}}) \mathrm{x}^{\mathrm{R}} & \mathrm{t} \text { even } \\
\pi_{\mathrm{t}}^{0}=\overline{\mathrm{x}}^{\mathrm{D}} & t \text { odd, D in office } \\
\pi_{\mathrm{t}}^{0}=\overline{\mathrm{x}}^{\mathrm{R}} & \text { t odd, R in office }
\end{array}
$$

Equations (11) and (12) underscore that in the first period of a new administration there is expectation uncertainty because contracts have to be signed before the elections. In the second period expectations are correct since the public has learned the identity and thus the preferences of the policymaker in office; thus there is no uncertainty. The implications of (12) for the output equation are as follows:

$$
y_{t}^{D}=\gamma(1-\bar{P})\left(\bar{x}^{D}-\bar{x}^{R}\right)+\bar{y} \quad \text { if } D \text { elected in period } t
$$




$$
\begin{aligned}
y_{t}^{R}=-\gamma \overline{\vec{P}}\left(\bar{x}^{D}-\bar{x}^{R}\right)+\vec{y} & \text { if } R \text { elected in period } t \\
y_{t+1}=\bar{y} & \text { if } D \text { or } R \text { elected in period } t
\end{aligned}
$$

Thus, a recession occurs in the first half of a Republican administration and an expansion in the first half of a Democratic administration. There is no difference in output in the second halves of the two administrations.

These are the empirical implications successfully tested by Alesina and Sachs (1988) and Alesina (1988a). We now proceed to consider the role of "Congress" in this model, by assuming that in the second period of his term of office, the President is constrained in policymaking by the composition of Congress. Thus, voters use the midterm election to counterbalance the President in office: in every mid-term election the party of the President in office loses votes relative to the preceding election.

We assume that if an $R$ President is in office in period t+l (assuming that Presidential elections took place in period r) the inflation policy is given by:

$$
\pi_{t+1}^{R}-\bar{x}^{R}+k v^{D R} \quad k>0
$$

where $\mathrm{V}^{\mathrm{DR}}$ is the share of votes received by party $D$ in the Congressional elections held at the beginning of period $t+1$. If President $D$ is in office in period $t+1$ the inflation policy is given by:

$$
\pi_{t+1}^{D}=\vec{x}^{D}-q\left(1-v^{D D}\right) \quad q>0
$$

where $\mathrm{V}^{\mathrm{DD}}$ is the share of votes received by party $\mathrm{D}$ in the Congressional elections held at the beginning of period $t+1 . \quad v^{D R}$ and $v^{D D}$ will be derived endogenously. For simplicity and with no loss of generality we also assume that: 


$$
\vec{x}-q>\vec{x}^{R}+k
$$

The linearity of the functions (14) and (15) helps in solving the model but it is not crucial for the qualitative features of the results. In other words, the results derived below are not of the "knife edge" type; namely, they hold for other specifications of relationships between $V^{D R}$ and $V^{D D}$ and $\pi_{t+1}^{R}$ and $\pi_{t+1}^{D}$ in which the curvature of the function is not too far from lineartity. Finally, for expositional purposes we assume, for the moment, that in the first period of his term of office the President is unconstrained by the composition of Congress. ${ }^{13}$

The model is solved by backward induction, in order to insure dynamic consistency; thus, we start from the mid-term elections which take place in period $t+1$. Consider first the case in which an $R$ President is in office in period $t$. We want to find $V^{D R}$ under the assumption that the voters know the effect of the composition of Congress on policymaking, namely they know (14). We make use of the following notion of equilibrium:

Definftion: A voter equilibrium occurs if and only if no voter would prefer a decrease in the expected vote for the party he voted for.

Since voters have single peaked preferences, there exists a cutpoint in the distribution of voters' bliss points, labeled $x^{*}$, such that every voter with a bliss point higher than $x^{\star}$ votes for party $D$ and vice versa. Given the uniform distribution ( 8 ), $\mathrm{x}^{\star}$ satisfies:

$$
v^{D R}=1+a-x^{*}
$$


It is immediate to show (by contradiction) that $x^{*}$ is such that $\vec{x}^{D}>x^{*}>\bar{x}^{R}$.

The expected utility (when the President $R$ is in office) of voter $i$ with a bliss point $x^{1}$, such that $\bar{x}^{D}>x^{i}>\vec{x}^{R}$, can be written, using (14) and (17) as : ${ }^{14}$

$$
E U^{R 1}-\int_{a^{\min }}^{a^{\max }}-\frac{1}{2}\left(\bar{x}^{R}+k\left(1+a-x^{*}\right)-x^{1}\right)^{2} f(a) d a
$$

We can then establish the following result:

Proposition 1: The unique cutpoint $x^{*}$ is given by: $x^{\star}-\frac{\bar{x}^{R}+k}{1+k}$.

Proof: Given our definition of equilibrium, a necessary and sufficient condition to identify the bliss point of the pivotal voter is the following:

$$
\frac{\partial E U^{R i}}{\partial x^{*}} \geq 0 \quad \text { if } x^{i} \leq x^{*}
$$

Thus :

$$
\frac{\partial E U^{R i}}{\partial x^{\star}}-\int_{a \min }^{a^{\max }}\left(-x^{R}+k\left(1+a-x^{\star}\right)-x^{1}\right) k f(a) d a
$$

Remembering that $\int_{a^{\min }}^{a^{\operatorname{mex}}}$ af(a) -0, (20) implies that:

$$
\frac{\partial E U^{R i}}{\partial x^{*}} \geq 0 \text { if } x^{\star} \leq \frac{\bar{x}^{R}+k}{1+k}
$$

Therefore the unique cut point is $x^{\star}-\frac{\bar{x}^{R}+k}{1+k}$.

Thus, using (14), (17) and the result of proposition 1 we obtain: 


$$
\begin{gathered}
E\left(\pi_{t+1}^{R}\right)=\pi_{t+1}^{*}=x^{*}=\frac{\bar{x}^{R}+k}{1+k} \\
\pi_{t+1}^{R}=\frac{\bar{x}^{R}+k}{1+k}+k a
\end{gathered}
$$

Consider the case in which a President $D$ is in office In perlod $t$ and define the cutpoint $\overline{\mathrm{x}}$ by:

$$
v^{D D}-1+a-\bar{x}
$$

By repeating the same procedure descrlbed before we obtain: ${ }^{15}$

$$
\begin{gathered}
E\left[\pi_{t+1}^{R}\right]=\pi_{t+1}^{0}-\bar{x}-\frac{\bar{x}^{D}}{1+q} \\
\pi_{t+1}^{D}-\frac{\bar{x}^{D}}{1+q}+q a
\end{gathered}
$$

We now turn to the Presidential election of period $t$. (Recall that we are assuming that in the first period the President is unconstrained by Corrress). The voters have all the information necessary to know which policy would be followed by the two parties in period $t$; in addition voters can compute the expected policies for period $t+1$ by using (21) and (24). Thus, in period $t$ voter $i$ with preferences $u^{1}$, votes for $D$ if and only if the following holds :

$$
E\left\{u^{i}\left(\vec{x}^{D}\right)+\beta u^{i}\left(\pi_{t+1}^{D}\right)\right\}>E\left\{u^{1}\left(-x^{R}\right)+\beta u^{i}\left(\pi_{t+1}^{R}\right)\right\}
$$

Equation (26) underscores that voter $i$ is better off if a $D$ President is elected in period $t$ taking account of the expected effects of the mid-term congressional elections. Thus, the voters for President $D$ have bliss points 
satisfying the following inequality:

$$
\frac{\beta\left\{\left[E\left[\pi_{t+1}^{D}\right)\right]-\left[E\left[\pi_{t+1}^{R}\right)\right]^{2}+\operatorname{var}(a)\left(q^{2}-k^{2}\right)\right\}+\bar{x}^{2}-\bar{x}^{R^{2}}}{2\left\{\left(\bar{x}^{D}-\bar{x}^{R}\right)+\beta\left[E\left[\pi_{t+1}^{D}\right)-E\left(\pi_{t+1}^{R}\right)\right]\right\}}
$$

In (27) $E\left[\pi_{t+1}^{D}\right)$ and $E\left[\pi_{t+1}^{\mathrm{g}}\right)$ are defined by equations (21) and (24), and $\operatorname{var}(a)$ is the variance of $a$.

Let us define $\hat{x}$ as the bliss point of the voter who is indifferent between voting $R$ or $D$ for President in period $t$; thus $\hat{x}$ is such that (27) holds as an equality. In Appendix $A$, the following result is shown:

Proposition 2: If $q-k$, then the following inequalities hold:

$$
\overrightarrow{\mathrm{x}}<\mathrm{x}^{*}<\hat{\mathrm{x}}<\overline{\mathrm{x}}<\overrightarrow{\mathrm{x}}^{\mathrm{D}}
$$

This result is consistent with the empirical observation that the party of the President always loses votes in mid-term elections. In fact Proposition? shows that there are always voters who switch from the party of the President to the opposing party in order to counterbalance the President's policy in the second half of his term. If $q \neq k$, namely one of the two potential Presidents is more responsive than the other to the composition of Congress, the inequalities of Proposition 2 still hold if $\operatorname{var}(a)$ is not too big (see Appendix A).

Proposition 2. also establishes a relationship between the economic outcome in the first half of each administration and the mid-term electoral results. The basic point is that, ceteris paribus, the more polarized are the two parties bliss points, i.e., the more distant are $\vec{x}$ and $\vec{x}$, the 
bigger the deviation of output growth from its natural level and the larger the fraction of voters switching from one party to the other in the mid-term elections. In fact, consider an increase in the distance between $\vec{x}$ and $\vec{x}$, such that the cutpoint of the Presidential election ( $\hat{x}$ ) remains unchanged; thus the probability of electing President $D$ or $R$ remains unchanged. In this situation, from (13) it follows that the deviation of output from its natural level $(\bar{y})$ increases, $i . e$, one observes a bigger expansion (recession) in the first half of a $D,(R)$ administration. For instance, consider the case in which $\mathrm{R}$ wins the Presidential elections. Since $\overrightarrow{\mathrm{x}}$ has decreased, so does $\mathrm{x}^{*}$ [from (21)]. This implies that a larger fraction of voters switches from party $R$ to party $D$ in mid-term elections.

The same qualitative implications for the mid-term electoral cycle holds if Congress is elected every period, i.e., in Presidential election years as well as in off years. In this case, the voters can achieve some counterbalancing effect in the first period too. The complete solution of this case is presented more extensively in Alesina and Rosenthal (1988). Here we simply sketch the solution of the first period problem, in order to show that the mid-term electoral cycle survives this generalization.

When both elections (Congressional and Presidential) occur contemporaneously in the first period two cutpoints are relevant: $\hat{x}^{P}$, the cutpoint for the Presidential election and $\hat{x}^{C}$ the cutpoint for the Congressional election. The expected utility of voter $i$ depends upon both cutpoints. Let us define as "interior" an equilibrium in which $\hat{x}^{z}$ and $\hat{x}^{C}$ satisfy the following conditions: 


$$
\begin{aligned}
& \left.\frac{\partial \operatorname{EU}^{i}\left(\hat{x}^{P}, \hat{x}^{C}\right)}{\partial \hat{x}^{P}}\right|_{x^{i}=\hat{x}^{P}}=0 \\
& \left.\frac{\partial E U^{i}\left(\hat{x}^{P}, \hat{x}^{C}\right)}{\partial \hat{x}^{C}}\right|_{x^{i}-\hat{x}^{C}}=0
\end{aligned}
$$

Alesina and Rosenthal (1988) show that, in general, an "interior" equilibrium exists and fully characterize it. The first period equilibrium in general manifests ticket-splitting, i.e. $\hat{x}^{P} \neq \hat{x}^{C}$. For the purpose of the present paper it is sufficient to establish the following result:

Proposition $3:$ If an interior equilibrium in the first period exists, then:

$$
\mathrm{x}^{*}<\hat{\mathrm{x}} \boldsymbol{c}<\tilde{\mathrm{x}}
$$

Proof: Suppose not. For given $\hat{x}^{P}, \hat{x}^{C}$ satisfies the following condition:

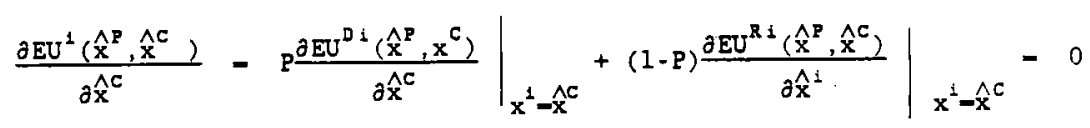

where $P$ - probability of electing a Democratic president, which is a constant for a given $\hat{x}^{P} ; E^{D 1}(\cdot)$ - expected utility of voter $\mathcal{L}$ if $D$ is elected and $\mathrm{EU}^{\mathrm{R} 1}(\cdot)$ - expected utility if $R$ elected. It is immediate to show that if $\hat{x}^{C}$ $\leq x^{*}$ or $\hat{x}^{C} \geq \tilde{x}, \frac{\partial E U^{D i}\left(\hat{x}^{P}, \hat{x}^{C}\right)}{\partial \hat{x}^{C}}$ and $\frac{\partial E U^{R i}\left(\hat{x}^{P}, \hat{x}^{C}\right)}{\partial \hat{x}^{C}}$ either have the same sign or one is zero and the other non-zero. Therefore (31) cannot be satisfied.

Q.E.D.

The intuition of this result is straightforward. If, say, $\hat{x}^{c}<x^{*}$ then the voters with bliss points $x^{i}$ such that $\hat{x}^{c}<x^{i}<x^{*}$ act as follows: in the first period, under uncertainty about the President's identity, they vote $D$ for Congress: this implies that they would want to counterbalance an $R$ 
president. In the second period when they know that an $R$ president is in office, they switch to voting $R$ for Congress, reducing the counterbalancing effect. This benavior cannot be rational, thus $\hat{x}^{c}<\mathrm{x}^{*}$ cannot be an equilibrium. Analogous argument holds for $\hat{x}^{C}>\tilde{x}$.

\section{Aggregate Results for Congressional Elections 1950-1984}

Our empirical analysis focuses on House and Senate elections from 1950 to 1984. Undoubtedly, some previous investigators had shied away from Senate data because only two-thirds of the states hold senate elections in a given election year. In fact, results for the Senate are qualitatively similar to those for the House. Testing for "class" effects by including dumm variables generally proved negative. ${ }^{16}$

\section{Incumbency Models}

We begin our data analysis by considering the simplified model of the political process developed in the preceding section. In the model, we assumed a perfectly stable environment except for the stochastic variation in the distribution of voter ideal points; consequently, no variation is predicted in the Presidential vote other than that induced by the stochastic process. Thus, the simple model does not suggest any systematic variation in either the Presidential vote or the Congressional vote in "on" years. ${ }^{17}$ In "off" years, in contrast, the model predicts an increase in the vote for the Republicans when the Democrats hold the White House and vice-versa. Given the small number of data points, we assume the two balancing effects to be equal. Thus, we have the following specification:

$$
\mathrm{V}_{\mathrm{R}, t}=\beta_{0}+\beta_{1} \mathrm{M}_{t}+\epsilon_{t}
$$

where $V_{R, t}=$ Republican Percentage of Two Party vote in year $t$. 


$$
\begin{aligned}
& M_{t}=1 \text {, if Dem. Incumbent Pres. and } t \text { is "off" year } \\
& -1 \text {, if Rep. Incumbent Pres. and } t \text { is "off" year. } \\
& 0 \text {, otherwise }
\end{aligned}
$$

and $\epsilon_{t}$ satisfies the standard OLS assumptions (consistent with our model.)

As to the coefficients, we hypothesize $\beta_{0}, \beta_{1}>0$. As shown in Column 1 of Tables $2 A$ and $2 B$, the simple model is supported by the data, with conventional significance levels at 0.05 or better. The model predicts that the two-party vote will split near its long-term average in Presidential years and favor the "outs" by 3.28 in the Senate and 1.88 in the House in midterm elections.

Our simple model captures part of the aggregate fluctuations, but leaves much unexplained variance, An alternative model emphasizes a systematic incumbency effect pertaining to both on and off years. We thus define

$$
\begin{aligned}
I_{t}= & +1 \text {, if Democrat Incumbent President } \\
& -1 \text {, if Republican Incumbent President }
\end{aligned}
$$

This incumbency variable was included in the specifications of Kramer (1971) and Fair (1978, 1982, 1987). As seen in Column 2 of Table 2, the standard incumbency variable, by itself, does not furnish explanatory power beyond that available in the midterm model.

In addition to the standard incumbency variable, Fair has considered an additional incumbency measure. He defines

$$
\begin{aligned}
& \mathrm{DEPR}_{t}=+1, \quad \begin{array}{l}
\text { if Democrat Incumbent President runs for } \\
\text { reelection in an "on" year. }
\end{array} \\
& -1, \quad \begin{array}{l}
\text { if Republican Incumbent President runs for } \\
\text { reelection in an "on" year. } \\
0, \text { otherwise }
\end{array}
\end{aligned}
$$

Following Fair (1987), Gerald Ford is treated as a non-incumbent in 
1976. As shown in Column 3 of Table 2, inclusion of DEPR by itself leaves our estimate of the midterm effect virtually unaffected, although the fit for the Senate is improved substantially. However, when $M, I$, and DEPR are all included in the model, there is a strong increase in fit and the midterm effect becomes unimportant (Column 4). Indeed, of the various incumbency models, the best, in terms of the ex post estimated standard error, model includes only I and DEPR, shown in Column (5) of Table 2.

With respect to the results in Colum (5), note that a midterm effect is still maintained. It is given by the coefficient on $I$ and is $2.1 \%$ in the House and $3.3 \%$ in the Senate, quite close to the original estimates in Column (1). On the other hand, Column (5) contradicts the simple model's hypothesis of only random variation in Presidential years. When the incumbent runs for reelection, his Congressional party reaps benefits (equal to the I coefficient - the DEPR coefficient). This incumbency bonus is 1.18 in the House and 3.28 in the Senate.

The DEPR results need, however, to be viewed with caution. If we let I* - I - $M$, then regressing on $I^{*}$ and $M$ is equivalent to regressing on $I$ and $M$. In turn, DEPR differs from $I^{*}$ only in its treatment of 4 observations, one of which involves the dubious coding of Ford. As Fair (1987) also noted for the Presidency, changing the Ford coding decision substantially alters the results. The column (4) $\mathrm{R}^{2}$ values drop from 0.546 to 0.400 for the House and from 0.796 to 0.678 for the Senate. The DEPR coefficient is not significant at the 0.05 level in either Colunn (4) or (5) for the House. More fundamentally, DEPR is not entirely a variable that is predetermined before the electoral period. Truman in 1952 and Johnson in 1968 were both eligible for reelection. In both cases, their decision not to pursue another term may 
have reflected their and their party's temporary unpopularity as a result of prolonged military conflicts in Asia. Consequently, DEPR might well be regarded as an encogenous variable, and columns (3) - (5) are subject to simultaneous equations bias. ${ }^{18}$

What is truly predetermined is whether the chief executive is a lame duck. Only two observations in our sample, 1960 and 1976 , are in this lame duck situation. If $D E P R$ is recoded to differentiate lame ducks from others, there is a further drop in $R^{2}$, to 0.363 for Column (4) for the House and to 0.526 for the House, while the lesser improvement afforded over Column (2) now depends solely on two observations, 1960 and 1976. All in all, there is reason to regard the DEPR effects with skepticism. Nonetheless, the results suggest that Presidential election years contain important lagged incumbency effects that are not captured in our simple model, which treats each four year term as an independent event.

\section{Economic Influences Models}

Another set of alternatives to our simple model is posed by various models of economic influences on voting behavior. The essence of the Kramer-Fair models is that the incumbent does well in good times. Growth in real per capita GNP, real per capita income, unemployment, and the inflation rate have been used as indicators of performance. Fair and Kramer find the strongest effects for the first two indicators and Bloom and Price (1975) consider only the second. Consequently, we restrict ourselves to the first two measures denoted by 8 and 1 respectively. ${ }^{19}$ Because we have few observations, and in order to avoid collinearity, we use these measures one at a time. Kramer (1971), Fair (1978), and Bloom and Price (1975) all use annual data for the year of the election. Fair (1987) concludes in favor of 
even shorter voter horizons and used data for the second and third quarters preceding the election. We consider both variants.

There are several possible models. ${ }^{20}$ One, noted by Kramer for historical reasons, but not investigated, is that the Republicans do well in good times. From the viewpoint of our theoretica: model, this "traditional" lore is in fact plausible, since "good times", defined in terms of high GNP growth, but with inflation, should tend to occur in the first half of a Democratic Presidency. The regressor for this model, when GNP is the indicator, would simply be 8 . In the Kramer-Fair models, good times favor the incumbent so the regressor is $-g I$. Bloom and Price adapt the Kramer model to allow for a "switching" regression. In recessions $(g<0)$, voters react to performance more than in expansions. The Bloom-Price model can be written:

$$
\begin{aligned}
V_{R, t} & =\beta_{0}+\beta_{1}\left[-g_{t}^{+} g_{t} I_{t}\right]+\beta_{2}\left[-\left(1-g_{t}^{+}\right) g_{t} I_{t}\right]+\epsilon_{t} \\
\text { where } g_{t}^{+} & =1 \text { if } g_{t}>0 \\
& =0 \text { otherwise. }
\end{aligned}
$$

The hypothesis of the model is that $\beta_{2}>\beta_{1} \geq 0$.

In contrast to these models, our simple approach suggests that if economic factors relate to voting at all it will only be a spurious correlation produced by the expectation uncertainty of economic agents and the moderating behavior of voters. The relevant economic variable should be deviation from trend. We consider $(g-\alpha)^{2} I$, where $\alpha$ is a target level for the economy. As in the other models, the coefficient on this variable should be positive. We either set $\alpha$ equal to the average growth rate of the economy over the time period of our data set or treat $\alpha$ as a parameter to be estimated by non-linear least squares. Another interpretation of this model is that voters are retrospective but more "sophisticated" than the "naive" 
voters of Kramer, Fair, and Bloom and Price. Sophisticated voters do not view too high growth in the short run as desirable. Such growth may be seen as potentially inflationary or, more generally, voters prefer a stable growth path rather than fluctuations of growth. ${ }^{21}$

Note that not all observations discriminate among the models. Our squared deviation model will look much like a Republican prosperity model as long as prosperity occurs when the Democrats are in office and recessions occur during Republican administrations. Similarly, squared deviations parallel Bloom and Price in calling for recessions to be severely punished. Squared deviations and Kramer-Fair basically agree for $g<\alpha$. Consequently, with only 18 observations it is difficult to discriminate between the models. 22

We begin our discussion of "economic" models by considering simple GNP models, using growth rates from the year of election, as shown in Table 3 . An immediate observation is that none of the models substantially outperform any of the incumbency models, including the very simple midterm effects model. The Kramer-Fair model does particularly poorly, and the Bloom-Price model also does not do very well. None of these "naive" retrospective regressions passes the standard 0.05 level. In terms of the standard error of the estimate (SE) both are dominated by the "Prosperity" and "Squared Deviation" models. The negative results for the Kramer-Fair and Bloom and Price models are important when viewed in the context of these authors' results. In Kramer's original paper, a simple economic model, based on real income, was highly significant. As he added variables to this initial regression, the economic growth varlable remained the driving variable. In the case of Bloom and Price, the simple model was the only one they 
presented. Our results indicate that these earlier retrospective voting models are not robust to alterations in the time period and data series.

The "Prosperity" model does poorly for the House but quite well for the Senate. The "Squared Deviation" model with fixed $\alpha$ is moro stable. The squared deviation variable is significant for both houses. The slope estimates for the House and Senate are quite similar. Estimating the "target" parameter $\alpha$ improves the fit slightly in the House and substantially in the Senate. The data, however, do not permit obtaining precise estimates of both $\alpha$ and the coefficient on the squared deviation. We thus cannot reject the null hypothesis that $\alpha=2.959$, the average GNP growth rate in the 1950-84 period. On the whole, the evidence in Tables 2 and 3 is at least as supportive of our balancing model than of retrospective voting models.

Result 1. Simple retrospective voting models do not outperform the altemative model that Republicans do well under prosperity.

Result 2. Simple retrospective voting models do not outperform the alternative model that incumbents are punished for deviations from a target level of growth.

Result 3. None of the models based on GNP growth rates for the year of the election fits the data substantially better than the simple midterm effect model [Column (1) of Table 2.]

One important claim of proponents of retrospective voting models is that the horizon employed by the voters is very short. However, our theoretical model would suggest that two years, rather than one year, prior to the election would be relevant. The reason is that the spurious correlation between voters' moderating behavior and the partisan business cycle is likely to be improved by the averaging implied by including data for both years 
prior to an election. Consequently, we reestimated all the models shown in Table 3 by also including all relevant variables lagged one year. Results are shown in Table 4. To save space, we group the 8 variables for the various models in a block of lines. The variables and their order are as shown in Table 3 .

Our hypothesis concerning the squared deviation models is confirmed. For fixed $\alpha$, both lagged coefficients are significant. ${ }^{23}$ Consistent with the averaging we expected, we cannot reject the hypothesis that the coefficients on the squared deviation variables are equal When $\alpha$ is estimated, there is a significant improvement in the log-likelihood for both houses. At the same time, the retrospective voting models are "improved" for the Senate (but not the House). The F-test for Kramer-Fair is significant. The driving variable, with the wrong sign, is lagged GNP. Bloom and Price's lagged recession variable is also significant. Their model shows at least as large an effect from negative growth one year prior to the election as in the year of the election. Although the coefficients are not estimated precisely, the House runs are similar--retrospective voting models show larger effects from the lagged data.

Result 4. The data do not support the claims of voter myopia found in the retrospective voting literature.

Result 5. The squared deviation models are significantly improved by including GNP data for the year preceding the election year.

To address the emphasis found in Kramer and Bloom and Price, we redid all the regressions in Tables 3 and 4 using $i$ in place of $\mathbf{g}$. For brevity, we summarize the results in the following statement.

Result 6. The income measure is not a good candidate for an explanatory 
variable in simple economic models of aggregate Congressional voting. The fits are generally worse than those for the GNP variable; when the fits are better, coefficient values are not as hypothesized by the naive retrospective voting models.

In his series of studies on Presidential voting, Fair has also focused on real GNP as the main predictor. Fair (1987) claims (at least for Presidential elections) that it is mainly per caplta growth in the second and third quarters of an election year that matters. Consequently, we also estimated the models of Table 3 and the no lags columns of Table 5 with $\mathbf{g}_{t}$ redefined to be the annualized per capita growth in quarters 2 and 3 of year $t^{24}$ Again the results are negative. The Prosperity and Kramer-Fair models are always worse for the two-period growth rate than for the growth rate for all of the election year. The squared deviation model is better for the House, with incumbency and trend, worse elsewhere. The Bloom and Price model does better in the House run $\left(R^{2}=0.292\right.$ vs. 0.184$)$ but worse in the Senate $(0.087$ vs 0.213$)$.

Our comparisons of the various models of economic influences on voting behavior have been limited to simple linear regressions including an economic variable and its lag or, in the case of Bloom and Price, a piecewise linear regression. The literature, however, includes variables that measure non-economic influences. Specifically, both Kramer and Fair included I and $t$ (time trend) as additional regressors. Results, presented in Table 5 , comparing the Kramer-Fair model and the Squared Deviation model when $I$ and $t$ are included, are quite instructive.

All the results in Table 5 must be viewed with caution, given the number of coefficients relative to degrees of freedom. Indeed, only two of the 8 
F-tests (testing the null hypothesis that all coefficients, save the constant, are zero) for the overall regression are significant at the 0.05 level. Neither of the two models dominates. Without the lagged variable, the Kramer-Fair model always has a better fit than the squared deviation. Indeed, the lagged variable does not noticeably improve the fit for this specification, in line with the previous restrospective voting lore. However, the Squared Deviation model, with the lag, is nearly as good as the Kramer-Fair model for the House and substantially better for the Senate.

Result 7. In a specification including an Incumbency variable and a time trend, there is no clear case for a Kramer-Fair retrospective voting model based on short memory vs, a squared Deviation Model in which lags are important.

What is most interesting about Table 5, however, is the pattern of the coefficients. Introducing incumbency into the Kramer-Fair model makes a dramatic difference in fit. (Compare Table 5 with Tables 3 and 4). Incumbency costs the "ins" about 2.28 of the vote in the House and 3.58 in the Senate. These figures are quite close to our original estimate of the midterm effect. While GNP growth now has the correct sign, it clearly has a subsidiary role to incumbency and has a significant coefficient only in the House runs. For GNP growth to have an effect roughly equal to that of incumbency, growth would have to fall from its average level of around 38 to about -28--a major recession level attained by only 1982 in the data or accelerate to $8 \%$-.a boom level that occurred only before the 1950 election.

In contrast to the Kramer-Fair model, the Squared Deviation model estimates never show a significant incumbency effect. The estimates are never as much as one-third those in the corresponding Kramer-Fair model; the 
estimates for incumbency are actually negative in the lagged model. Adding incumbency helps the overall fit of the original simple model only slightly. The GNP coefficient estimates retain the signs found in Tables 3 and 4 but are significant only in the lagged model for the Senate. What has happened is that the coefficients are not precisely estimated as a result of the predicted colinearity between $I$ and $(8-\alpha)^{2} I$.

When we run a full (less the weak, non-significant inflation variable) Fair (1987) model by including DEPR, we obtain results similar to the simple regression shown in Table 2. Just as the $M$ coefficient was near zero when both I and DEPR were included, the Squared Deviation coefficients are near zero when DEPR is added to the model of Table 5. While the naive retrospective 8 variable is slightly more successful in this context (again a lagged version is more favorable to Squared Deviations), the critical variables in Fair's specifications are non-economic. In both houses, the change in GNP growth from the average would have to be over $10 z$ for the estimated impact to equal that of $I$. Such a change is beyond all the sample values of 8 . Similarly, according to the DEPR model, a party will gain more from getting its incumbent to stand for another term than it could ever possibly achieve by successful management of the economy. Although the DEPR model puts a twist on Presidential factors not captured in our model, the basic empirical results square with the thrust of our model -- elections are not driven by economic performance but by forces internal to the political process.

Our simple theory, of course, also predicts that the Squared Deviation model will not improve on the simple midterm effect variable $M$. This observation brings us directly to our empirical punch line. Neither GNP 
variable improves on our simple midterm effect model. We show this in Table 6, where the I dummy variable in Table 5 has simply been replaced by $M$ (The I variable still appears in the $\mathbf{g}$ variables.) Substituting $M$ for $I$ in $a$ classical Kramer model is something of a draw-the House results are worse and the Senate results are better. In both cases, however, GNP growth has a negligible effect. The only significant coefficient appears in the lagged Senate model, but there the lagged coefficient has the wrong sign while the sum of the two coefficients is roughly zero. A similar story holds for Squared Deviations. Here the $\mathrm{R}^{2}$ is better than with $I$ for both Senate and House. No coefficients are significant in the House run whereas they are significant when $M$ and Squared Deviations are run separately. The lack of significance in Table 6 reflects the anticipated colinearity between the two variables. One lagged coefficient is significant in the senate, but, no surprise at this point, the unlagged coefficient has the wrong sign.

Result 8. Simple models of economic influences add little, if anything, to the basic midterm effects model.

\section{Conclusion}

We have presented a very simple but internally consistent macro model of an economic and political system. The model is obviously very crude, and further theoretical work is in order, on both bringing in dynamics that would enrich the two period focus of the current model and on relaxing simplifying technical assumptions. The model we have presented does, however, capture some critical features of some modern political systems.

The economic side of the model accounts for the notion that economic agents cannot be routinely fooled by the government. With rational 
expectations, anticipated efforts at manipulating the economy should have no effect on the real level of output. On the other hand, agents enter into contracts that are sufficiently long-term such that they can only attempt more or less successfully to hedge against the uncertainty generated by politics.

In addition to the assumption of voters' rationality, the political side of the model has three key features (1) a two-party system in which politicians are polarized; (2) policy reflects the influence of both the executive and the legislature; (3) an institutional structure where there are legislative elections while the executive remains in power. The United States and France are the two nations that are reasonably good fits to our stylized environment.

The upshot of our stylized "political economy" is that political polarization and uncertainty generates economic fluctuations and that voters use the legislative elections to attenuate the policy swings engendered by polarization. Within the context of our model, these concurrent economic and political events generate a purely spurious correlation between current economic conditions and voting behavior in the legislative elections.

In the empirical section of the paper, we saw evidence of the spurious correlation. The midterm effect portrayed by our model was strongly supported by the data, while various "economic" models of voting behavior falled to generate much additional explanatory power.

Our empirical results help to reconcile the findings from survey data that individual voting behavior is not responsive to changes in individual economic outcomes (Kinder and Kiewiet, 1979; Kiewiet, 1981) and the supposed regularity that aggregate voting behavior responds to aggregate economic 
conditions. While Kramer (1979) provided an elegant methodological reconciliation based on the observation that the survey questions failed to differentiate overall individual changes in economic fortunes from the portion of the change the individual attributed to government, our findings question the existence of the regularity for the postwar period, at least insofar as Congressional elections are concerned.

The near zero correlations we have obtained between standard "retrospective" regressors and Congressional outcomes contrasts with the very high $\mathbf{R}^{2}$ values Fair (1987) has obtained for presidential elections. Markus (1988), using survey data, also finds strong support for retrospective voting using survey data for the $1956-84$ period. $^{25}$ It is thus quite possible that both retrospective and moderating influences are present. In voting for the Presidency, voters use the past to evaluate the current Presidential party, but, having selected the chief executive, invariably choose moderation in the off year elections.

Our model has also not considered many other important influences on voting behavior, most notably the incentive that each voter has to feather his constituency's Congressional nest by continuing to reelect the current incumbent. The incumbency incentives are probably the major factor in Iimiting the midterm effect to only about 2.5 of the electorate. That the midterm effect exists at all responds to the fact that open seats arise and to the possibility that many individuals (professors who participate in national labor markets, retirees) are more responsive to the direction of national economy policy than to increments to local pork. 
'See the seminal works by Kramer (1971), Nordhaus (1975), and Hibbs (1977). ${ }^{2}$ See, however, the controversy between Beck (1982, 1984b) and Hibbs (1983). Hibbs (1987) has recently showed additional empirical evidence in favor of his view. For empirical evidence in European countries see Alt (1985).

${ }^{3}$ Chappell (1983) and Chappell and Keech (1985) also developed macro political economy models from this perspective.

"We treat these preferences as exogenous and do not model them. The presence of polarization during the postwar period is supported not only by casual observation but also by empirical studies of voter evaluations of Presidential candidates (Poole and Rosenthal, 1984a) of interest group evaluations of members of Congress (Poole and Daniels, 1985, Poole and Rosenthal, 1984b) and of roll call voting patterns (Poole and Rosenthal, $1985 a, 1985 b$ ).

SNote that labor contracts may last one, or even two years; thus even though some elections may not be very uncertain say two or three months before November, the electoral uncertainty relevant to these economic decisions is present say 12 or even 18 months before the election.

${ }^{6}$ Split-ticket voting undoubtedly also responds to many other influences, such as incumbency advantage and ethnic preference.

'See Alesina and Tabellini (1987) and McKibbin, Roubini and Sachs (1987) for two party models with state variables which link each administration with its successors.

${ }^{8}$ For models with learning and asymmetric information, see Cukierman and Meltzer (1986), Alesina and Cukierman (1987), Rogoff and Sibert (1988) and Rogoff (1987).

${ }^{9}$ For some results more favorable to Nordhaus see Haynes and Stone (1987) and Grier (1987).

${ }^{10}$ Alternatively, the model could be closed by a quantity theory equation such as $m_{t}-\pi_{t}+y_{t}$, where $m_{t}$ is the rate of money growth; in this case one could assume that the policymakers control money growth rather than inflation. The shortcut adopted in the text simplifies the notation without affecting in any way the results. In this paper, we disregard the issue of the partial independence of the Federal Reserve. See Alesina (1988a) on this issue in a related context.

${ }^{11}$ This simplification eliminates the issue of time inconsistency of optimal monetary policy in rational expectations models pointed out by Kydland and Prescott (1977) and Barro and Gordon (1983). The time inconsistency arises if the unexpected inflation term enters the utility functions of the two parties. By not including output in the objective functions such a term does not appear. Alesina (1987, 1988a) and Alesina and Sachs (1988) show extensively how to deal with this problem in two-party models. 
${ }^{12}$ Policy convergence can be achieved only if the electoral game is modelled as a repeated game, so that reputational mechanisms can be accounted for. See Alesina (1988b), Alesina and Cukierman (1987), Alesina and Spear (1987) for repeated electoral games with ideologically motivated politicians and Ferajohn (1986) and Rogoff and Sibert (1988) for repeated electoral games with purely office motivated politicians. In this paper we do not consider reputational mechanisms; $1 . e .$, we consider every election as a one-shot game.

${ }^{13}$ The specification adopted for the effect of Congress on policymaking is perhaps more appropriate for the case of proportional representation, which does not apply to the United States Congress.

${ }^{14}$ Note that (18) would not represent the correct expecited utility for the voters with bliss points $x^{J}$ such that $x^{J}<a^{\max }$ or $x^{J}>1+a^{m i n}$. In fact by knowing their preferences, and that the preference distribution is uniform, these voters can infer something about the realization of the random variable a. Thus their expected utility is not given by (18). Since, however, the cut point voter $\mathrm{x}^{*}$ has to lie in between $\vec{x}^{D}$ and $\vec{x}^{R}$, given condition (9), this consideration does not affect the proof of Proposition 1.

${ }^{15}$ Note that in the model with Congress, the realization of the random variable a can generate unexpected inflation or deflation even in the second perfod of any administration.

${ }^{16}$ Like Fair (1987), we report results based on the latest revisions of the data, which in the case of GNP, have been quite substantial. However, such a choice is problematic. Kramer (1979) argues that one should model voters as basing their decisions not on changes in their total income but on changes in income that they attribute to governmental activity. However, one may argue that voters' assessments reflect the "real" economy rather than the "unrevised" announcements made by the government in the period before election. We have checked our analysis with respect to GNP data by using the CITIBASE series prior to the 1986 revisions. The results from the older series are somewhat more favorable to the argument advanced in this paper.

${ }^{17}$ We do not include Presidential voting in this paper. We completely agree with Fair (1978), who, citing work by Lepper (1974), argues that it was unreasonable for Kramer (1971) to have estimated a model in which Presidential and House elections were considered in a single model with constrained coefficients.

${ }^{18}$ of course, it might well make sense, in the spirit of Fair's research, to include DEPR in a short-term (Truman announced his withdrawal on March 12 , 1952 and Johnson on March 30, 1968) forecasting model.

${ }^{19}$ Our work uses real GNP (net per capita). Results for annual per capita growth rates are very similar to those presented here.

${ }^{20}$ See also Arcelus and Meltzer (1975) and Tufte (1975).

${ }^{21}$ This view of the model is congruent with the approach of Chappell (1986) and Chappell and Keech (1986). The model with squared deviation also is congruent with Lepper's (1974) finding that incumbents lose votes when either unemployment or inflation is high. 
${ }^{22}$ In order to gain degrees of freedom, observations from the interwar period could be used. In this case, however, one has to make more and more heroic assumptions about the stability of the politico-economic environment and thus about the stability of coefficients. In addition, if one excludes the observations affected by the two World Wars and by the Great Depression, there are very few useful observations can be obtained for years prior to 1950 in this century.

${ }^{23}$ For the House, the F-test, which is equivalent to a two-tailed t-test here, is not significant whereas the one-tailed t-test on the lagged variable is.

${ }^{24}$ Like Fair (1987), we used $G_{t, q}$ - real GNP for quarter $q$ in year $t$ from CITIBASE file GNP82 and $P_{e}=$ quarterly population figures that Fair obtained from the Council of Economic Advisors. We computed $g$ from the formula: $g_{t}=100\left[\left(\frac{G_{t, 3} / P_{t, 3}}{G_{t, 2} / P_{t, 1}}\right)^{2}-1\right]$.

${ }^{25}$ See also Chubb (1988) on state legislative elections. 


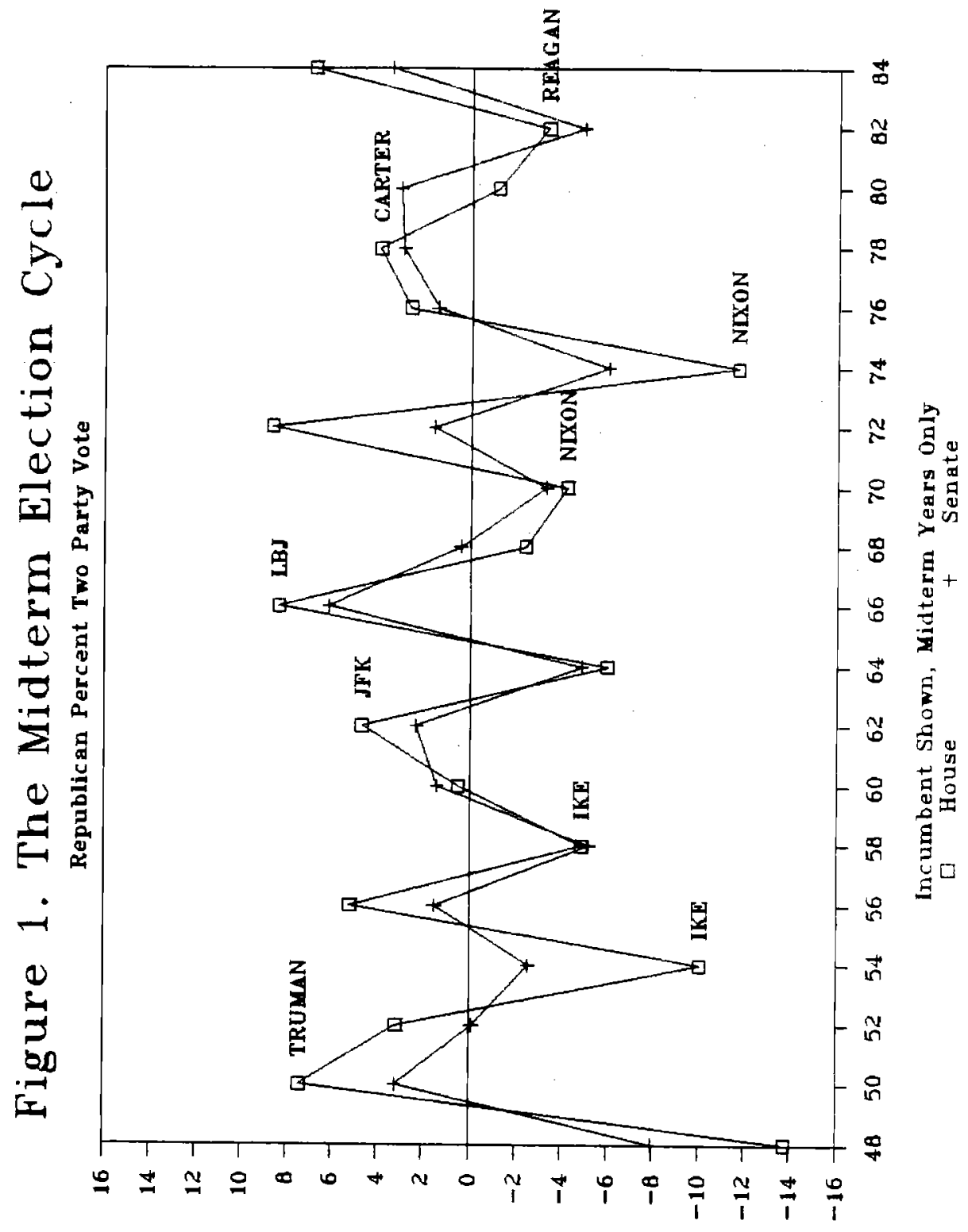

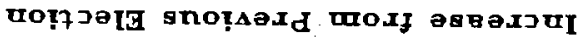


TABLE 1

Rate of Growth of GNP

(Constant Prices)

Democratic Administrations

Truman

Kennedy/Johnson

Johnson

Carter

Average

Average

First/Second Halves

\begin{tabular}{|c|c|c|c|}
\hline $\begin{array}{l}\text { First } \\
0.0 \\
2.6 \\
5.8 \\
4.7\end{array}$ & $\begin{array}{c}\text { Second } \\
8.5 \\
5.3 \\
5.8 \\
5.3\end{array}$ & $\begin{array}{r}\text { Third } \\
10.3 \\
4.1 \\
2.9 \\
2.5\end{array}$ & 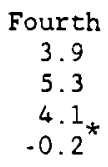 \\
\hline 3.3 & 6.2 & 5.0 & 3.3 \\
\hline
\end{tabular}

4.8

4.1

\section{Republican Administrations}

\section{Eisenhower I \\ Eisenhower II \\ Nixon \\ Nixon/Ford \\ Reagan I \\ Reagan II}

Average

First/Second Halves
Average

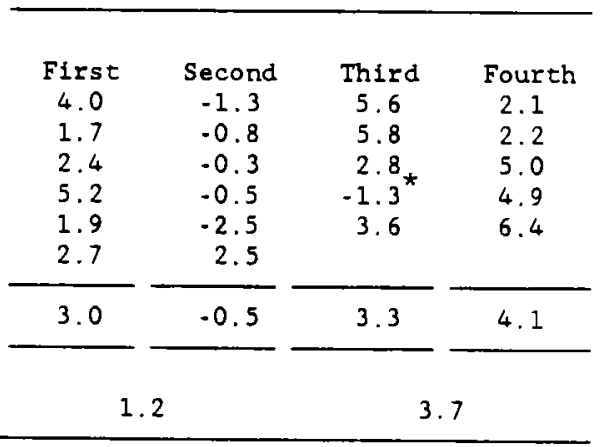

Source: Economic Report of the President 1987.

* Oil Shocks 
Table 2.

\section{Incumbency Regressions}

A. House of Representatives

(1)

$$
\begin{aligned}
& 46.473 \\
& (0.571)
\end{aligned}
$$

M-midterm

I-incumbent

DEPR

S.E.

$\mathrm{R}^{2}$

DW
(2)

(3)

$$
\text { (4) }
$$

$\begin{array}{lccccc}\text { Constant } & 46.473 & 46.507 & 46.409 & 46.409 & 46.426 \\ & (0.571) & (0.581) & (0.572) & (0.475) & (0.469) \\ \text { M-midterm } & 1.821 & 1.213 & 1.814 & -0.970 & \\ & (0.807) & (1.154) & (0.804) & (1.201) & \\ \text { I-incumbent } & & 0.612 & & 2.785 & 2.114 \\ \text { DEPR } & & (0.819) & & (0.998) & (0.548) \\ & & & -1.146 & -3.931 & -3.257 \\ \text { S.E. } & 2.415 & 2.449 & 2.405 & 1.996 & 1.973 \\ \text { R }^{2} & 0.241 & 0.269 & 0.294 & 0.546 & 0.525 \\ \text { DW } & 1.13 & 1.24 & 1.14 & 2.03 & 1.66\end{array}$
(1)
(2)
(3)
(4)

$\begin{array}{lccccc}\text { Constant } & 47.671 & 47.662 & 47.500 & 47.500 & 47.504 \\ \text { M-midterm } & (0.702) & (0.727) & (0.598) & (0.439) & (0.424) \\ & 3.213 & 3.368 & 3.194 & -0.239 & \\ \text { I-incumbent } & (0.993) & (1.445) & (0.841) & (1.111) & \\ & & -0.157 & & 3.433 & 3.268 \\ \text { DEPR } & & (1.025) & & (0.923) & (0.497) \\ & & & -3.061 & -6.494 & -6.328 \\ \text { S.E. } & 2.971 & 3.066 & 2.515 & 1.846 & 1.787 \\ \text { R }^{2} & 0.395 & 0.396 & 0.594 & 0.796 & 0.795 \\ \text { DW } & 1.84 & 1.83 & 1.88 & 2.76 & 2.70\end{array}$


Tablo 3

SLaple Economic Influences Regressions
A. House of Representatives,
g. annual

$\begin{array}{ccc}\text { Prosperity } & \text { Kramer- } \\ \text { Falr } & \text { Ploom- } & \text { Squared Deviacion } \\ & & \text { Flxed }\end{array}$

\begin{tabular}{|c|c|c|c|c|c|}
\hline Constant & $\begin{array}{l}45.451^{\circ} \\
(0.854)\end{array}$ & $\begin{array}{l}46.184^{\circ} \\
(0.666)\end{array}$ & $\begin{array}{l}46.599^{\circ} \\
(0.692)\end{array}$ & $\begin{array}{l}46.590^{\circ} \\
(0.573)\end{array}$ & $\begin{array}{l}46.828^{\circ} \\
(0.806)\end{array}$ \\
\hline 8 & $\begin{array}{c}0.311 \\
(0.195)\end{array}$ & & & & \\
\hline$-8 I$ & & $\begin{array}{l}-0.146 \\
(0.155)\end{array}$ & & & \\
\hline$-8^{+} 8 I$ & & & $\begin{array}{l}-0.158 \\
(0.149)\end{array}$ & & \\
\hline$=\left(1-8^{+}\right) 81$ & & & $\begin{array}{c}1.266 \\
(0.970)\end{array}$ & & \\
\hline$(z-a)^{2} I$ & & & - & $\begin{array}{c}0.101^{\circ} \\
(0.044)\end{array}$ & $\begin{array}{c}0.094 \\
(0.072)\end{array}$ \\
\hline$a$ & & & & $\begin{array}{l}2.959 \\
\text { 11xed }\end{array}$ & $\begin{array}{c}3.773^{\circ} \\
(1.876)\end{array}$ \\
\hline S. 8. & 2.575 & 2.698 & 2.586 & 2.398 & 2.233 \\
\hline$R^{2}$ & 0.137 & 0.053 & 0.184 & $0.252^{i}$ & $0.270^{\circ}$ \\
\hline DW & 1.46 & 2.05 & 1.51 & 1.45 & \\
\hline
\end{tabular}

B. Senate, 8. annual

$\begin{array}{cccc}\text { Prosperlty Kraen- } & \text { Blooa- } & \text { Squared Devilation } \\ \text { Falr } & \text { Prlce } & \text { Flxed } & \text { Est. }\end{array}$

\begin{tabular}{|c|c|c|c|c|c|}
\hline Conseane & $\begin{array}{l}45.309^{\circ} \\
(0.958)\end{array}$ & $\begin{array}{l}46.184^{\circ} \\
(0.666)\end{array}$ & $\begin{array}{l}48.171^{\circ} \\
(0.922)\end{array}$ & $\begin{array}{l}46.590^{\circ} \\
(0.573)\end{array}$ & $\begin{array}{l}48.539^{\circ} \\
(0.685)\end{array}$ \\
\hline 8 & $\begin{array}{c}0.738^{\circ} \\
(0.223)\end{array}$ & & : & & \\
\hline$-8 I$ & & $\begin{array}{l}-0.061 \\
(0.219)\end{array}$ & & & \\
\hline$-8+8 I$ & & & $\begin{array}{l}-0.083 \\
(0.199)\end{array}$ & & \\
\hline$\cdot\left(1-8^{+}\right) 8 I$ & & & $\begin{array}{c}2.577 \\
(1.253)\end{array}$ & & \\
\hline$(\varepsilon \cdot a)^{2} \mathrm{I}$ & & & & $\begin{array}{c}0.120^{\circ} \\
(0.062)\end{array}$ & $\begin{array}{c}0.062 \\
(0.081)\end{array}$ \\
\hline$a$ & & & & $\begin{array}{l}2.959 \\
\text { E1xed }\end{array}$ & $\begin{array}{c}7.000 \\
(4.330)\end{array}$ \\
\hline S.E. & 2.943 & 3.811 & 3.448 & 3.389 & 2.901 \\
\hline $\mathrm{R}^{2}$ & $0.406^{\dagger}$ & 0.005 & 0.236 & 0.213 & $0.350^{\dagger}$ \\
\hline DU & 2.28 & 2.68 & 2.33 & 2.53 & \\
\hline
\end{tabular}

$2 \ln L$

\footnotetext{
- Confflelene signifleanely differ froa 0 ae 0.05 lovel or beter (one-callod).

P.cesc for regression significane ac 0.05 lovel or bucter.
} 


\section{Table 4.}

Economic Influences, Lagged Regressions

A. House, 8 annual

\begin{tabular}{|c|c|c|c|c|c|}
\hline . & Prosperity & $\begin{array}{c}\text { Kramer- } \\
\text { Fair }\end{array}$ & $\begin{array}{l}\text { Bloom- } \\
\text { Price }\end{array}$ & $\begin{array}{l}\text { Squared } \\
\text { Fixed }\end{array}$ & $\begin{array}{c}\text { Deviation } \\
\text { Est. }\end{array}$ \\
\hline Constant & $\begin{array}{l}45.453^{\circ} \\
(1.219)\end{array}$ & $\begin{array}{l}46.300^{\star} \\
(0.666)\end{array}$ & $\begin{array}{l}47.041^{\circ} \\
(0.734)\end{array}$ & $\begin{array}{l}46.413^{*} \\
(0.535)\end{array}$ & $\begin{array}{l}46.828^{\star} \\
(0.806)\end{array}$ \\
\hline \multirow[t]{2}{*}{8 variables } & $\begin{array}{c}0.319 \\
(0.194)\end{array}$ & $\begin{array}{l}-0.048 \\
(0.191)\end{array}$ & $\begin{array}{c}0.045 \\
(0.214)\end{array}$ & $\begin{array}{c}0.084^{*} \\
(0.041)\end{array}$ & $\begin{array}{c}0.050 \\
(0.094)\end{array}$ \\
\hline & & & $\begin{array}{c}1.266 \\
(0.970)\end{array}$ & & \\
\hline $8_{-1}$ variables & $\begin{array}{l}0.272 \\
(0.243)\end{array}$ & $\begin{array}{l}-0.161 \\
(0.179)\end{array}$ & $\begin{array}{c}-0.171 \\
(0.196)\end{array}$ & $\begin{array}{c}0.075^{*} \\
(0.038)\end{array}$ & $\begin{array}{c}0.108 \\
(0.181)\end{array}$ \\
\hline$\alpha$ & & & $\begin{array}{c}3.581 \\
(2.333)\end{array}$ & $\begin{array}{l}2.959 \\
\text { fixed }\end{array}$ & $\begin{array}{r}4.671 " \\
(2.313)\end{array}$ \\
\hline $\begin{array}{l}\text { S.E. } \\
\text { R } \\
\text { DW } \\
2 \ln L\end{array}$ & $\begin{array}{l}2.555 \\
0.204 \\
1.60\end{array}$ & $\begin{array}{l}2.715 \\
0.101 \\
1.86\end{array}$ & $\begin{array}{l}2.538 \\
0.319 \\
1.82\end{array}$ & $\begin{array}{l}2.208 \\
0.405 \\
1.90\end{array}$ & $\begin{array}{r}1.816 \\
0.517^{\dagger} \\
-72.563\end{array}$ \\
\hline
\end{tabular}

B. Senate. 8 annual $\begin{array}{cccc}\text { Prosperity } & \begin{array}{c}\text { Kramer- } \\ \text { Fair }\end{array} & \begin{array}{l}\text { Bloom- } \\ \text { Price }\end{array} & \text { Squared Deviation } \\ \text { Fixed } & \text { Est. }\end{array}$

\begin{tabular}{|c|c|c|c|c|c|}
\hline Constant & $\begin{array}{l}43.641^{*} \\
(1.323)\end{array}$ & $\begin{array}{l}47.767^{\circ} \\
(0.941)\end{array}$ & $\begin{array}{l}48.810^{*} \\
(0.895)\end{array}$ & $\begin{array}{l}47.479^{\circ} \\
(0.722)\end{array}$ & $\begin{array}{c}47.929^{*} \\
(0.655)\end{array}$ \\
\hline \multirow[t]{2}{*}{8 variables } & $\begin{array}{c}0.751 \\
(0.211)\end{array}$ & $\begin{array}{c}0.238 \\
(0.242)\end{array}$ & $\begin{array}{c}0.365 \\
(0.260)\end{array}$ & $\begin{array}{c}0.100 \\
(0.055)\end{array}$ & $\begin{array}{c}0.104 \\
(0.088)\end{array}$ \\
\hline & & & $\begin{array}{c}2.109^{\star} \\
(1.182)\end{array}$ & & \\
\hline 8.1 variables & $\begin{array}{c}0.454 \\
(0.264)\end{array}$ & $\begin{array}{l}-0.488 \\
(0.227)\end{array}$ & $\begin{array}{l}-0.501 \\
(0.239)\end{array}$ & $\begin{array}{c}0.123^{*} \\
(0.051)\end{array}$ & $\begin{array}{c}0.129 \\
(0.218)\end{array}$ \\
\hline & & & $\begin{array}{c}4.736^{*} \\
(2.843)\end{array}$ & & \\
\hline$\alpha$ & & & & $\begin{array}{l}2.959 \\
\text { fixed }\end{array}$ & $\begin{array}{r}3.934 \\
(1.463)\end{array}$ \\
\hline $\begin{array}{l}S_{i} E \\
R^{2} \\
D W\end{array}$ & $\begin{array}{l}2.779 \\
0.504 \\
2.25\end{array}$ & $\begin{array}{l}3.440^{\dagger} \\
0.240^{\dagger} \\
2.30\end{array}$ & $\begin{array}{l}3.448 \\
0.468 \\
2.41\end{array}$ & $\begin{array}{l}2.978 \\
0.430^{\dagger} \\
2.66\end{array}$ & $\begin{array}{l}2.583 \\
0.485\end{array}$ \\
\hline
\end{tabular}

$2 \ln \mathrm{L}$

- Coefficient significantly differ from 0 at 0.05 level or better (one-tailed).

$+F$-test or likelihood ratio test for including lagged terms in regression significant at 0.05 leve 1 or better. 
Table 5.

Economic Influences Regressions: GNP, Incumbency, and Trend A. House

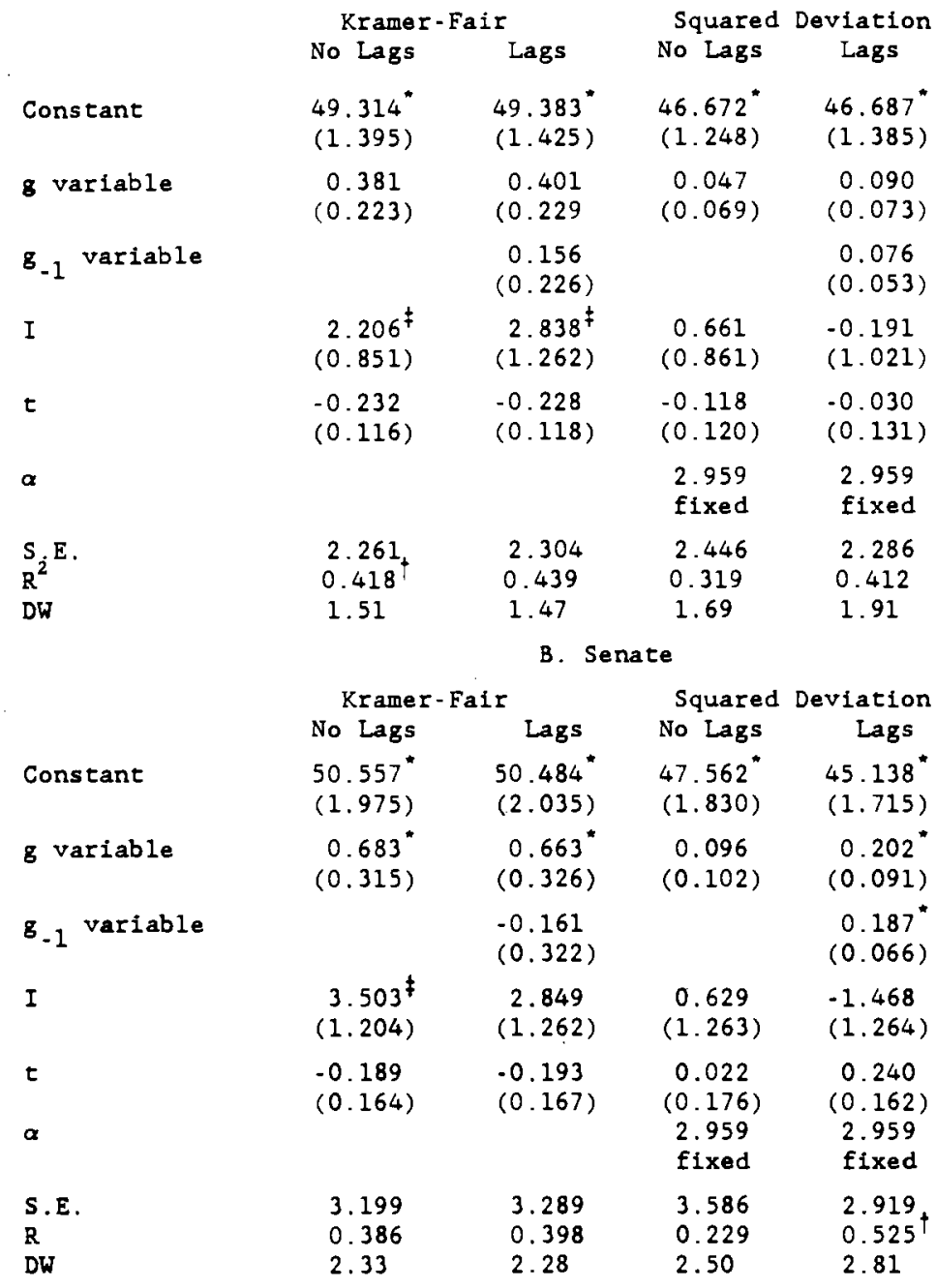

- Coefficient significantly differ from 0 at 0.05 level or better (one-tailed).

\$ Coefficient significantly differ from 0 at 0.05 level or better (two-tailed).

$\dagger$ F-test or likelihood ratio test for regression significant at 0.05 level or better. 
Table 6 .

Economic Influences Regressions: GNP, Midterm, and Trend

\begin{tabular}{|c|c|c|c|c|}
\hline \multirow[t]{2}{*}{ A. House } & \multicolumn{2}{|c|}{ Kramer-Fair } & Squared & \multirow{2}{*}{$\begin{array}{c}\text { Deviation } \\
\text { Lags }\end{array}$} \\
\hline & No Lags & Lags & No Lags & \\
\hline Constant & $\begin{array}{l}48.244^{*} \\
(1.437)\end{array}$ & $\begin{array}{l}48.427^{*} \\
(1.437)\end{array}$ & $\begin{array}{l}47.866^{*} \\
(1.260)\end{array}$ & $\begin{array}{l}47.083^{*} \\
(1.301)\end{array}$ \\
\hline 8 variable & $\begin{array}{c}0.071 \\
(0.164)\end{array}$ & $\begin{array}{c}0.126 \\
(0.194)\end{array}$ & $\begin{array}{c}0.016 \\
(0.084)\end{array}$ & $\begin{array}{c}0.022 \\
(0.080 .)\end{array}$ \\
\hline $8_{-1}$ variable & & $\begin{array}{l}-0.100 \\
(0.179)\end{array}$ & & $\begin{array}{c}0.066 \\
(0.042)\end{array}$ \\
\hline$M$ & $\begin{array}{c}1.838^{*} \\
(0.876)\end{array}$ & $\begin{array}{c}1.634 \\
(1.262)\end{array}$ & $\begin{array}{l}1.456 \\
(1.451)\end{array}$ & $\begin{array}{c}1.201 \\
(1.392)\end{array}$ \\
\hline$t$ & $\begin{array}{l}-0.177 \\
(0.120)\end{array}$ & $\begin{array}{l}-0.190 \\
(0.125)\end{array}$ & $\begin{array}{l}-0.145 \\
(0.124)\end{array}$ & $\begin{array}{l}-0.076 \\
(0.126)\end{array}$ \\
\hline$\alpha$ & & & $\begin{array}{l}2.959 \\
\text { fixed }\end{array}$ & $\begin{array}{l}2.959 \\
\text { fixed }\end{array}$ \\
\hline $\begin{array}{l}S_{i} E . \\
R^{2} \\
D W\end{array}$ & $\begin{array}{l}2.399 \\
0.345 \\
1.22\end{array}$ & $\begin{array}{l}2.460 \\
0.360 \\
1.22\end{array}$ & $\begin{array}{l}2.412 \\
0.338 \\
1.34\end{array}$ & $\begin{array}{l}2.297 \\
0.442 \\
1.71\end{array}$ \\
\hline B. Senate & Krame & air & Squared $\mathrm{D}$ & eviation \\
\hline & No Lags & Lags & No Lags & Lags \\
\hline Constant & $\begin{array}{l}49.032^{\circ} \\
(1.717)\end{array}$ & $\begin{array}{l}49.620^{\star} \\
(1.683)\end{array}$ & $\begin{array}{l}48.311^{*} \\
(1.636)\end{array}$ & $\begin{array}{l}46.768^{\star} \\
(1.470)\end{array}$ \\
\hline 8 variable & $\begin{array}{c}0.248 \\
(0.206)\end{array}$ & $\begin{array}{c}0.422^{*} \\
(0.227)\end{array}$ & $\begin{array}{l}-0.062 \\
(0.109)\end{array}$ & $\begin{array}{l}-0.051 \\
(0.090)\end{array}$ \\
\hline 8.1 variable & & $\begin{array}{l}-0.321 \\
(0.209)\end{array}$ & & $\begin{array}{r}0.130^{*} \\
(0.048)\end{array}$ \\
\hline $\mathbf{M}$ & $\begin{array}{c}3.697^{*} \\
(1.102)\end{array}$ & $\begin{array}{r}3.045^{*} \\
(1.262)\end{array}$ & $\begin{array}{c}4.074^{\star} \\
(1.885)\end{array}$ & $\begin{array}{r}3.570^{*} \\
(1.573)\end{array}$ \\
\hline$t$ & $\begin{array}{l}-0.177 \\
(0.120)\end{array}$ & $\begin{array}{l}-0.151 \\
(0.147)\end{array}$ & $\begin{array}{l}-0.076 \\
(0.161)\end{array}$ & $\begin{array}{c}0.060 \\
(0.142)\end{array}$ \\
\hline$\alpha$ & & & $\begin{array}{l}2.959 \\
\text { fixed }\end{array}$ & $\begin{array}{l}2.959 \\
\text { fixed }\end{array}$ \\
\hline $\begin{array}{l}S_{i} E \\
R^{2} \\
D W\end{array}$ & $\begin{array}{l}3.018 \\
0.454 \\
1.66\end{array}$ & $\begin{array}{l}2.881 \\
0.538 \\
1.44\end{array}$ & $\begin{array}{l}3.133 \\
0.412 \\
1.76\end{array}$ & $\begin{array}{l}2.596 \\
0.625 \\
1.91\end{array}$ \\
\hline
\end{tabular}

\footnotetext{
* Coefficient significantly differ from 0 at 0.05 level or better (one-tailed).

\$Cofficient significantly differ from 0 at 0.05 level or better (two-tailed).

$+F$-test or likelihood ratio test for regression significant at 0.05 level or better.
} 


\section{Appencix A}

Proof of Proposition 2.

The inequalities $\bar{x}^{R}<\mathrm{x}^{*}<\tilde{\mathrm{x}}<\overrightarrow{\mathrm{x}}$ can be easily established by using (9), (16), (21) and (24). The inequalities $\mathrm{x}^{*}<\hat{\mathrm{x}}<\tilde{\mathrm{x}}$ can be established as follows. If $q-k,(27)$ can be rewritten as an equalicy as follows:

$$
\hat{\mathrm{x}}-\frac{\beta\left[\overline{\mathrm{x}}^{2} \cdot \mathrm{x}^{\star^{2}}\right]+\overline{\mathrm{x}}^{2}-\overline{\mathrm{x}}^{2}}{2\left[\left(\overline{\mathrm{x}}-\overline{\mathrm{x}}^{\mathrm{R}}\right]+\beta\left[\overline{\mathrm{x}}-\overline{\mathrm{x}}^{\star}\right)\right]}
$$

We want to show first that

$$
\overline{\mathrm{x}}>\hat{\mathrm{x}}
$$

Using (A-1), (A-2) implies after rearrangement:

$$
2 \overline{\mathrm{x}}\left[\overrightarrow{\mathrm{x}}-\overrightarrow{\mathrm{x}}^{\mathrm{R}}\right]+2 \beta \tilde{\mathrm{x}}\left[\tilde{\mathrm{x}}-\mathrm{x}^{\star}\right]>\beta\left[\overline{\mathrm{x}}-\mathrm{x}^{*}\right]\left[\mathrm{x}^{*}+\overrightarrow{\mathrm{x}}\right]+(\overrightarrow{\mathrm{x}}-\overrightarrow{\mathrm{x}})\left(\overrightarrow{\mathrm{x}}+\overrightarrow{\mathrm{x}}^{\mathrm{R}}\right)
$$

or:

$$
\left(\overline{\mathrm{x}}^{\mathrm{D}}-\overline{\mathrm{x}}^{\mathrm{R}}\right]\left[2 \tilde{\mathrm{x}} \cdot\left(\overline{\mathrm{x}}^{\mathrm{D}}+\overline{\mathrm{x}}^{\mathrm{R}}\right)\right]+\beta\left[\overline{\mathrm{x}} \cdot \mathrm{x}^{*}\right)^{2}>0
$$

The second term in (A-4) is positive; the first is also positive, if:

$$
\overline{\mathrm{x}}>\frac{\overrightarrow{\mathrm{x}}^{\mathrm{D}}+\overline{\mathrm{x}}^{\mathrm{R}}}{2}
$$

If $q-k$, (16) implies the following inequalities:

$$
\vec{x}-k>\frac{\vec{x}^{D}+\vec{x}^{R}}{2}>\vec{x}+k
$$

Condition (9) implies $0<v^{D D}<1$, which implies $\bar{x}>\bar{x}^{D}-k$. Consequently, (A-6) implies (A-5). Thus (A-6) holds. By repeating the same procedure one obtains that $\hat{x}>x^{*}$ if and only if

$$
\left(\overrightarrow{\mathrm{x}}-\overrightarrow{\mathrm{x}}^{\mathrm{R}}\right)\left(2 \mathrm{x}^{*}-\left(\overrightarrow{\mathrm{x}}+\overrightarrow{\mathrm{x}}^{\mathrm{R}}\right)\right)-\beta\left(\overline{\mathrm{x}}-\mathrm{x}^{*}\right)^{2}<0
$$


Using (16) and $(A-6)$ one can easily show that (A-7) holds.

Q.E.D.

Consider now the case of $q \neq k$. The inequalities corresponding to $(A-4)$ and $(A-7)$ are as follows:

$$
\begin{aligned}
& \left(\vec{x}-\vec{x}^{R}\right)\left(2 \vec{x} \cdot\left(\bar{x}+\bar{x}^{R}\right)\right)+\beta\left(\bar{x}-x^{*}\right)^{2}>\left(q^{2}-k^{2}\right) \operatorname{Var}(a) \\
& \left(-\bar{x}-\bar{x}^{8}\right)\left(2 x^{*}:\left(-\bar{x}+\bar{x}^{-8}\right)\right)-\beta\left(\tilde{x}-x^{*}\right)^{2}<\left(q^{2}-k^{2}\right) \operatorname{Var}(a)
\end{aligned}
$$

(A-8) and (A-9) show what is claimed in the text, precisely that Proposition 2 holds also for $q \neq k$ as long as $q$ and $k$ are not too different or $v a r(a)$ is not too high. 


\section{Appendix B}

\section{Data}

\begin{tabular}{|c|c|c|c|c|c|c|c|}
\hline Year & $\begin{array}{r}\text { Republ } \\
\text { Shar } \\
\text { Two-Pa } \\
\text { Vote }\end{array}$ & $\begin{array}{l}\text { ican } \\
\text { e } \\
\text { rty }\end{array}$ & $\begin{array}{l}\text { Growth } \\
\text { Real G }\end{array}$ & $\begin{array}{l}\text { Rate, } \\
\text { P }\end{array}$ & $\begin{array}{l}\text { Growth Rate, } \\
\text { Real GNP. } \\
\text { 2nd, 3rd } \\
\text { Quarters }\end{array}$ & $\begin{array}{l}\text { Growt } \\
\text { Real } \\
\text { per }\end{array}$ & $\begin{array}{l}\text { h Rate } \\
\text { Income } \\
\text { Capita }\end{array}$ \\
\hline & House & Senate & 8 & 8.1 & per Capita & $i$ & $i_{-1}$ \\
\hline 1950 & 49.959 & 50.534 & 8.539 & 0.027 & 12.109 & 7.062 & -1.995 \\
\hline 1952 & 49.844 & 53.712 & 3.902 & 10.345 & -0.337 & 2.580 & 2.465 \\
\hline 1954 & 47.272 & 43.665 & -1.329 & 4.004 & -0.145 & -1.249 & 3.571 \\
\hline 1956 & 48.797 & 48.905 & 2.059 & 5.555 & -0.688 & 3.919 & 5.590 \\
\hline 1958 & 43.603 & 44.027 & -0.766 & 1.670 & 4.199 & -1.393 & 0.376 \\
\hline 1960 & 45.029 & 44.534 & 2.219 & 5.835 & -1.917 & 1.600 & 3.729 \\
\hline 1962 & 47.363 & 49.235 & 5.310 & 2.608 & 2.477 & 3.551 & 1.249 \\
\hline 1964 & 42.498 & 43.247 & 5.336 & 4.108 & 2.380 & 4.266 & 2.332 \\
\hline 1966 & 48.673 & 51.617 & 5.787 & 5.792 & 1.434 & 4.470 & 5.170 \\
\hline 1968 & 49.078 & 49.189 & 4.152 & 2.852 & 4.002 & 4.242 & 3.224 \\
\hline 1970 & 45.775 & 44.989 & -0.292 & 2.436 & 0.948 & 0.420 & 2.695 \\
\hline 1972 & 47.335 & 53.679 & 4.980 & 2.839 & 5.054 & 5.138 & 1.808 \\
\hline 1974 & 41.323 & 42.013 & -0.536 & 5.195 & -2.951 & -1.973 & 4.676 \\
\hline 1976 & 42.754 & 44.635 & 4.887 & -1.259 & 0.781 & 3.530 & -1.553 \\
\hline 1978 & 45.678 & 48.590 & 5.290 & 4.669 & 7.072 & 3.648 & 2.979 \\
\hline 1980 & 48.714 & 47.394 & -0.160 & 2.476 & -5.694 & -3.328 & -0.254 \\
\hline 1982 & 43.782 & 44.039 & -2.546 & 1.931 & -2.009 & -1.226 & 0.098 \\
\hline 1984 & 47.220 & 50.862 & 6.429 & 3.572 & 2.693 & 4.110 & 1.992 \\
\hline
\end{tabular}




\section{REFERENCES}

Alesina, Alberto (1987). "Macroeconomic Policy in a Two-Party System as a Repeated Game", Quarterly Journal of Economics, Vol. 102, $651-78$, (August).

(1988a). "Macroeconomics and Politics" in NBER Macroeconomic Annual 1988, MIT Press, forthcoming.

System with Rational Voters", American Economic Review, forthcoming.

and Alex Cukierman (1987). "The Politics of Ambiguity", NBER Working Paper, No. 2468, (December).

- and Jeffrey Sachs (1988). "Political Parties and the Business Cycle in the United States, 1948-1984", Journal of Money Credit and Banking, 63-82, (February).

and Howard Rosenthal (1988). "The Theory of Moderating Elections", in preparation.

and Stephen Spear (1987). "An Overlapping Generations Model of Electoral Competition", NBER Working Paper, No. 2354, (July).

and Guido Tabellini (1987). "A Positive Theory of Fiscal Deficits and Government Debt", NBER Working Paper, No. 2308, (July).

Alt, James (1985). "Political Parties, World Demand and Unemployment: Domestic and International Sources of Economic Activity", American Political Science Review, Vol. 79, 1016-1040, (December).

Arcelus, Francisco and Allan Meltzer (1975). "The Effects of Aggregate Economic Variables on Congressional Elections", American Political Science Review, Vol. 69, 1231-39, (December).

Barro, Robert and David Gordon (1983). "Rules, Discretion and Reputation in a Model of Monetary Policy", Journal of Monetary Economics, Vol. 12, 101-22, (July).

Beck, Nathaniel (1982). "Parties, Administrations and American Macroeconomic Outcomes", American Political Science Review, Vol, 76, 83-94, (March).

(1984a). "Domestic Political Sources of American Monetary Policy: 1955-82", Journal of Politics, Vol. 46, 786-817, (August). Vo1. $78,499-504$, (June).

Black, Duncan (1958). Theory of Committees and Elections, Cambridge University Press, Cambridge, MA. 
Bloom, Howard and Douglas Price (1975). "Voter Response to Short-rur Economic Conditions: The Asymmetric Effects of Prosperity anc Recessions", American Political Science Review, Vol. 69, 1240.54, (December).

Calvert, Randall (1985). "A Robustness of the Multidimensional Voting ModeI Candidate Motivations, Uncertainty and Convergence", American Journal of Political Science, Vol. 29,69-95, (February).

Chappell, Henry W., Jr.(1983). "Presidential Popularity and Voter Performance: Are Voters Really So Naive?" Review of Economics anc Statistics, Vol. $65,385-90$. and William R. Keech (1985). "A New View of Political
Accountability for Economic Performance", American Political Science
Review, Vol. 79, 10-27, (March).

and (1988). "The Unemployment Consequences of Partisat Monetary Policy", unpublished.

Chubb, John E. (1988). "Institutions, the Economy, and the Dynamics of State. Elections", Americal Political Science Review, Vol. 82, 133-154, (March).

Cukierman, Alex and Allan Meltzer (1986). "A Theory of Ambiguity, Credibility and Inflation under Discretion and Asymmetric Information", Econometrica, Vol. 53, 1099-128, (September).

Downs, Anthony (1957). An Economic Theory of Democracy, Harper and Row, New York.

Fair, Ray (1978). "The Effects of Economic Events on Votes for Presidents", The Review of Economics and Statistics, Vol. 60, 159-72, (May).

(1982). "The Effect of Economic Events on Votes for President: 1980 Results", The Review of Economic and Statistics, Vol. 64, 322.25, (May).

1988 (1987). "The Effect of Economic Events on Votes for President: 1988 Update", National Bureau of Economic Research, Working Paper No. 2222, (April), forthcoming in Political Behavior

Ferejohn, John (1986). "Incumbent Performance and Electoral Control", Public Choice, vol. 50, 5-26.

Fiorina, Morris (1981). Retrospective Voting in American National Elections, New Haven: Yale University Press.

Grier, Kevin (1987). "Presidential Elections and Federal Reserve Policy". Southern Economic Journal, Vol. 54, 475-86.

Havrilesky, Thomas (1987). "A Partisan Theory of Fiscal and Monetary Regimes", Journal of Money Credit and Banking, Vol. 19, 308-25, (August). 
Haynes, Stephen and Joe Stone (1987). "Should Political Models of the Business Cycle be Revived?", University of Oregon Working Paper No. 8716 .

Hibbs, Douglas (1977). "Political Parties and Macroeconomic Policy", The American Policical Science Review, Vol. 71, 1467-1487, (December).

Vol. 77, 135-138, (March).

(1987). The American Polifical Economy: Electoral Policy and Macroeconomics in Contemporary America, Harvard University Press, Cambridge, MA.

Kiewiet, D. Roderick (1981). "Policy-oriented Voting in Response to Economic Issues", American Political Science Review, Vol. 75, 448-59.

Kinder, Donald R. and D. Roderick Kiewiet (1979). "Economic Discontent and Political Behavior: The Role of Personal Grievances and Collective Economic Judgments in Congressional Voting", American Journal of Political Science, Vol. 23, 495-527.

Kramer, Gerald (1971). "Shore Term Fluctuations in U.S. Voting Behavior, 1896-1964", American Policical Science Review, Vol. 65, 131-43, (March).

(1983). "The Ecological Fallacy Revisited: Aggregate versus Individual-Level Findings on Economics and Elections and Sociotropic Voting", American Policical Science Review, Vol. 77, 92-111, (March).

Kydland, Finn and Edward Prescott (1977). "Rules Rather than Discretion: The Inconsistency of Optimal Plans", Journal of Political Economy, vo1. $85,473-490$, (June).

Lepper, Susan (1974). "Voting Behavior and Aggregate Policy Targets", Public Choice, Vol. 18, 67-82.

Markus, Gregory B. (1988). "The Impact of Personal, National and Economic Conditions on the Presidential Vote: A Pooled Cross-Sectional Analysis", American Journal of Political Science, Vol. 32, 137-154 (March).

McCallum, Bennete (1978). "The Political Business Cycle: An Empirical Test", Southern Economic Journal, Vol. 44, 504-515, (January).

McKibbin, Warwick, Nuriel Roubini and Jeffrey Sachs (1987). "Dynamic Optimization in Two-Party Models", NBER Working Paper, (April).

Nordhaus, William (1975). "The Political Business Cycle", Review of Economic Seudies, Vol. 42, 169-190, (April).

Poole, Keith T. and R. Steven Daniels (1985). "Ideology, Party, and Voting in the U.S. Congress, 1959-80", American Political Science Review, Vol. $79,373-399$, (June). 
Poole, Keith T. and Howard Rosenthal (2984a). "U.S. Presidential Elections 1968-1980: A Spatial Analysis", Anerican Journal of Political Science, Vo1. 28, 283-312, (May).

and

(1984b). "The Polarization of American Politics", Journal of politics, Vol. 46, 1061-1079.

and (1985a).

"A Spatial Model for Legislative Roll Call Analysis", American Journal of Political Scienc, Vol. 29, 357-84.

- and (1985b). "The Political Economy of Roll Call Voting in the 'Multi-Party' Congress of the United States", European Journal of Political Economy, Vol. 1, 45-58.

Rogoff, Kenneth (1987). "Political Budget Cycles" National Bureau of Economic Research working paper.

and Anne Sibert (1988). "Equilibrium Political Business Cycles", Review of Economic Studies, Vol. 55, 1-16, (January).

Tabellini, Guido and Vincenzo La Via (1986). "Money, Debt and Deficits in the U.S.", unpublished (forthcoming in Review of Economics and Statistics).

Tufte, Edward B. (1975). "Determinant of the Outcomes of Midterm Congressional Election", American Political Sclence Review, Vol. 69 , $812 \cdot 826$, (September).

Wittman, Donald (1977). "Candidates with Policy. Preferences: A Dynamic Mode1", Journal ef Economic Theory, Vo1. 14, 180-189, (February).

(1983). "Candidate Motivation: A Synthesis of Alternatives", American Political Sclence Review, Vol. 77, 142-57, (March). 